\title{
THE TOTAL WHITE CELL COUNT OF THE BLOOD AS AN INDICATOR OF ACUTE RADIATION DAMAGE AND ITS VALUE DURING THE FIRST FEW HOURS AFTER EXPOSURE
}

\author{
BY \\ E. V. HULSE \\ From the Medical Research Council Radiobiological Research Unit, Harwell, Didcot, Berks, England
}

(RECEIVED FOR PUBLICATION OCTOBER 1, 1959)

\begin{abstract}
The total white cell count of the blood is of no value in assessing the degree of acute radiation damage in rats during the first 48 hours after exposure. This is because there is a transient neutrophilia after irradiation which counteracts, to a varying extent, the reduction in numbers of the other white cells. A similar neutrophilia occurs in human patients and there is no reason to expect that the total white cell count over the same period would be of any greater value in man. It is suggested, therefore, that the total white cell count of the blood is not suitable as a method for sorting radiation casualties.
\end{abstract}

In recent years it has been suggested that routine blood counts are not suitable as controls of chronic radiation exposure (Mole, 1954 ; Loutit, 1955). However, during the weeks following single large exposures to radiation it is well known that there is a marked reduction in the numbers of the various types of white cells, and detailed examinations of the blood would normally be undertaken in the investigation of small numbers of casualties from excessive exposure to ionizing radiations (Hempelmann, Lisco, and Hoffman, 1952; Guskova and Baisogolov, 1956; Bond, Cronkite, Farr, and Hechter, 1956; Jammet, Mathé, Pendic, Duplan, Maupin, Latarjet, Kalic, Schwarzenberg, Djukic, and Vigne, 1959).

The prognosis of radiation casualties and the choice of treatment depend on the degree of radiation damage and this, in turn, depends on the dose of radiation received. Physical measurements of the dose are, however, unlikely to be available in the first few hours after an emergency involving ionizing radiation, whether it be a peace-time accident or a consequence of nuclear warfare. A clinical assessment of the degree of radiation damage is therefore required. As the number of white cells in the blood some time after a single exposure depends fairly closely on the magnitude of the radiation dose received, it has often been assumed that there will be a similar relationship between dose and effect within the first few hours of exposure. Consequently it has also been assumed that, if laboratory facilities became overloaded because of the number of casualties, it might be possible to use the total white cell count as a means of assessing damage. With this end in view a rapid method of estimating the total white cell count has recently been described and its accuracy considered (Benjamin, 1958; Sanders, Cox, and Sharples, 1958). The accuracy of the method, however, is of no account unless the early changes in white cell numbers do indeed reflect the degree of radiation exposure.

Although the marked leucopenia which occurs some time after irradiation is well recognized, the changes in the leucocyte count occurring during the first 18-24 hours do not appear to be as well known. In particular their implications regarding the use of the total white cell count as an indicator of radiation damage do not seem to have been considered. The object of this investigation has been, therefore, to examine some experimental data from this point of view. It will be shown that the observations indicate that it is not justifiable to rely solely on the total white cell count as an indicator of the degree of exposure to ionizing radiation.

\section{Methods}

Heart blood was obtained from rats in which the effects of irradiation on the bone marrow were also being studied. Details of the experimental methods are given in previous reports on other 
aspects of the data obtained (Hulse, 1957; 1959a and b). The total white cell counts were performed in the usual manner; two pipettes were filled from each animal and two chambers counted from each pipette, i.e., about 500 cells were counted when dealing with a control. Blood smears were stained by the Jenner-Giemsa method and a differential count performed on 200 cells.

The whole body was irradiated with $240-250 \mathrm{kV}$ $x$ rays and the dose rate was $43 \mathrm{r} / \mathrm{min} .-68 \mathrm{r} / \mathrm{min}$. A detailed description of the irradiation methods has been given by Corp (1957). One series of animals was given doses ranging from $25 \mathrm{r}$ to $10,000 \mathrm{r}$ and killed at 24 hours after irradiation. A second series was used to study the changes in the white cell count at times ranging from two to 72 hours after irradiation. For this second series three doses of radiation were used: $100 \mathrm{r}$, a dose much too small to cause acute deaths; $600 \mathrm{r}$, a dose which gives a mortality of about $50 \%$ in the strain of rats used ; and 5,000 r, a dose which is uniformly fatal within a few days and is between five and six times that which gives a mortality of $100 \%$ from acute radiation damage. Either three or four animals were examined at each dose or time interval, except at 24 hours after 25 r, when six animals were examined. The two series were studied concurrently, and the results for 24 hours after $100 \mathrm{r}, 600 \mathrm{r}$, and 5,000 r refer to the same groups of animals in each case.

\section{Results}

Total White Cell Counts.-The total white cell count at 24 hours after various doses of irradiation is shown in Fig. 1. A reduction in the white cell count as the radiation dose increases is apparent, although between $100 \mathrm{r}$ and 1,000 $\mathrm{r}$ there was only a threefold change in the mean counts of groups of irradiated animals. Any estimation of the dose

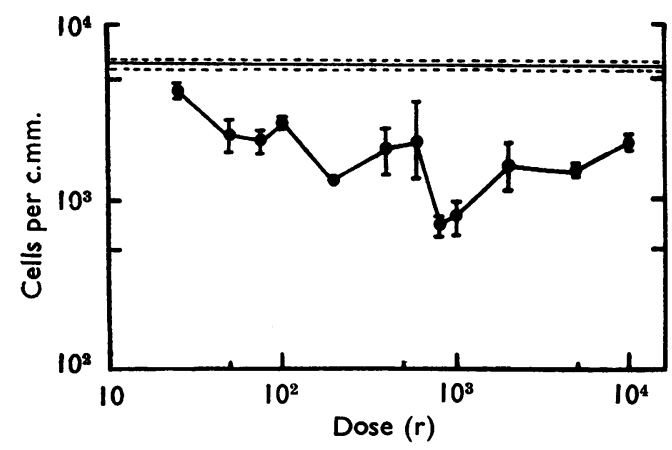

FIG. 1.-Total white cells per c.mm. of blood (means \pm standard errors on a logarithmic scale) at 24 hours after irradiation and dose of radiation in roentgens (logarithmic scale). The control value is indicated by a continuous horizontal line and its standard error by interrupted lines above and below it. $200 \mathrm{r}$ point: only two animals were studied at this dose. A standard error has not therefore been given. of radiation received by an individual from the total white count at 24 hours after exposure is, therefore, likely to be very uncertain. In addition, it is evident from Fig. 1 that the leucopenia did not depend on dose in a simple uncomplicated manner, the lowest counts being obtained after $800 \mathrm{r}$ and $1,000 \mathrm{r}$ even though the dose range extended to $10,000 \mathrm{r}$.

The response of the total white cell count at various times after $100 \mathrm{r}, 600 \mathrm{r}$, and $5,000 \mathrm{r}$ is shown in Fig 2. There was a rapid fall in white

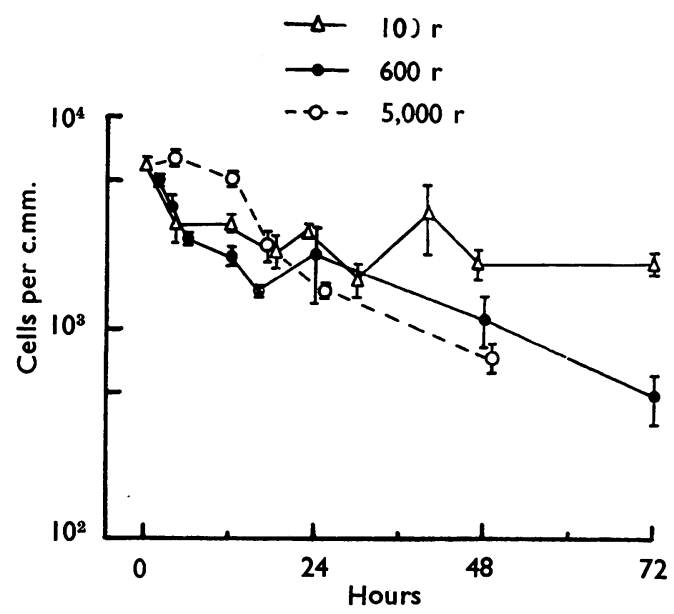

FIG. 2.-Total white cells per c.mm. of blood (means \pm standard errors on a logarithmic scale) and time after irradiation in hours for three doses, $100 \mathrm{r}, 600 \mathrm{r}$, and $5,000 \mathrm{r}$.

cells in the first few hours after $100 \mathrm{r}$ and $600 \mathrm{r}$. The magnitude of the fall was very similar for the two doses, and it was only at times after irradiation greater than 30 hours that differences between these two doses began to be evident. After the larger dose of $5,000 \mathrm{r}$ there was initially a much smaller reduction in the white cell count than after the smaller doses. In fact very little change in numbers from the control level occurred during the first 12 hours, and it was not until 18 to 24 hours after irradiation that the total leucocyte count was depressed as much as it was after $100 \mathrm{r}$ and $600 \mathrm{r}$. Even at 48 hours the degree of leucopenia after $5,000 \mathrm{r}$ was not significantly greater than that after $600 \mathrm{r}$.

There were therefore two findings during the first few hours after irradiation which require explanation: (1) The reduction in the total white cell count after a lethal dose was no greater than that after a much lower sublethal dose, and (2) the total white cell count remained within normal limits for 12 hours after a very high dose. 
In order to understand these changes it is necessary to consider how the individual lines of cells respond to irradiation.

Differential Counts.-The data on the various types of white cell are shown in Tables I and II, which correspond to Figs. 1 and 2 respectively. At 24 hours after irradiation there was a progressive decrease with increasing dose in the absolute numbers of eosinophils, lymphocytes, and monocytes (Table I). The responses of the segmented and juvenile neutrophils were, however, rather different, the counts showing no significant

TABLE I

ABSOLUTE NUMBERS OF BLOOD LEUCOCYTES AT 24 HOURS AFTER IRRADIATION

\begin{tabular}{|c|c|c|c|c|c|}
\hline $\begin{array}{l}\text { Dose } \\
\text { of } \\
\text { Radia- } \\
\text { tion } \\
\text { (r) }\end{array}$ & $\begin{array}{l}\text { Segmented } \\
\text { Neutrophils } \\
\text { (per c.mm.) }\end{array}$ & $\begin{array}{c}\text { Juvenile } \\
\text { Neutro- } \\
\text { phils } \\
\text { (per } \\
\text { c.mm.) }\end{array}$ & $\begin{array}{c}\text { Eosino- } \\
\text { phils } \\
\text { (per } \\
\text { c.mm.) }\end{array}$ & $\begin{array}{l}\text { Lym } \\
\text { (pe }\end{array}$ & $\begin{array}{l}\text { Mono- } \\
\text { cytes } \\
\text { (per } \\
\text { c.mm.) }\end{array}$ \\
\hline $\begin{array}{r}25 \\
50 \\
75 \\
100 \\
200 \\
400 \\
600 \\
800 \\
1,000 \\
2,000 \\
5,000 \\
10,000\end{array}$ & $\begin{array}{c}691(137) \\
350(73) \\
724(207) \\
904(229) \\
735^{*} \\
1,480(470) \\
1,840(830) \\
556(94) \\
644(147) \\
1,450(410) \\
1,310(110) \\
1,870(220)\end{array}$ & $\begin{array}{r}78(12) \\
62(2) \\
98(27) \\
137(34) \\
125^{*} \\
142(26) \\
106(50) \\
46(20) \\
61(31) \\
71(40) \\
103(15) \\
251(56)\end{array}$ & $\begin{array}{c}104(38) \\
70(42) \\
94(45) \\
50(14) \\
18 * \\
40(9) \\
21(5) \\
17(2) \\
11(5) \\
12(7) \\
4+ \\
0\end{array}$ & 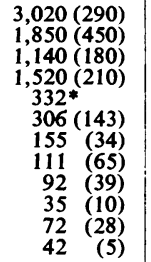 & $\begin{array}{c}264(46) \\
119(13) \\
124(30) \\
162(29) \\
67^{*} \\
57(23) \\
43(18) \\
37(14) \\
25 \dagger \\
16(5) \\
11(5) \\
8 \dagger\end{array}$ \\
\hline Ontiofis & $1,040(90)$ & $151(17)$ & $104(12)$ & $4,450(260)$ & $275(22)$ \\
\hline
\end{tabular}

Standard errors in parentheses.

* Only two animals were studied at this dose and the standard errors have not therefore been given.

† Standard errors omitted as, in each case, one of the animals gave a zero value. difference from the controls over the range of $75 r-600 r$ but showing real decreases after lower doses $(25 \mathrm{r}$ and $50 \mathrm{r})$ and after higher doses ( $800 \mathrm{r}$ and $1,000 \mathrm{r}$ ). The most striking change, however, occurred after still higher doses when both types of granulocyte increased in numbers and after $10,000 \mathrm{r}$ were well above normal.

The responses of the different cell types at various times after irradiation are shown by the data given in Table II. The reduction in the numbers of eosinophils, lymphocytes, and monocytes increased with the passage of time after the two higher doses, and similar but less marked changes occurred after $100 \mathrm{r}$. During the first 24 hours the segmented and juvenile neutrophils were reduced to not more than half their normal numbers after $100 \mathrm{r}$ but were increased to double normal values after $600 \mathrm{r}$ and to four times normal after 5,000 r. The increases were already evident at two and four hours after irradiation when the first examinations were made, and the maximum recorded response was found at 12 hours after 5,000 r. A neutrophilia may, therefore, occur after irradiation. It was not found after low doses but was present after higher doses, when its duration and its magnitude increased as the dose was increased.

It is thus apparent that the reason why the total white cell count did not change during the first 12 hours after $5,000 \mathrm{r}$ is that the postirradiation lymphopenia was completely balanced by the neutrophilia. The similarity in the response of the total white count after $100 \mathrm{r}$ and $600 \mathrm{r}$

TABLE II

ABSOLUTE NUMBERS OF BLOOD LEUCOCYTES AT VARIOUS TIMES AFTER IRRADIATION

\begin{tabular}{|c|c|c|c|c|c|c|}
\hline $\begin{array}{l}\text { Dose of } \\
\text { Radiation } \\
\text { (r) }\end{array}$ & $\begin{array}{l}\text { Time after } \\
\text { Irradiation } \\
\text { in Hours }\end{array}$ & $\begin{array}{l}\text { Segmented } \\
\text { Neutrophils } \\
\text { (per c.mm.) }\end{array}$ & $\begin{array}{c}\text { Juvenile } \\
\text { Neutrophils } \\
\text { (per c.mm.) }\end{array}$ & $\begin{array}{l}\text { Eosinophils } \\
\text { (per c.mm.) }\end{array}$ & $\begin{array}{l}\text { Lymphocytes } \\
\text { (per c.mm.) }\end{array}$ & $\begin{array}{l}\text { Monocytes } \\
\text { (per c.mm.) }\end{array}$ \\
\hline 5,000 & $\begin{array}{r}4 \\
12 \\
18 \\
24 \\
30 \\
40 \\
48 \\
72 \\
2 \\
4 \\
4 \\
6 \\
12 \\
16 \\
24 \\
48 \\
72 \\
4 \\
12 \\
18 \\
24 \\
48\end{array}$ & $\begin{array}{r}800(51) \\
560(55) \\
591(179) \\
904(229) \\
428(50) \\
793(238) \\
742(139) \\
541(100) \\
2,590(343) \\
2,230(290) \\
1,590(140) \\
1,220(290) \\
1,100(70) \\
1,840(830) \\
971(220) \\
340(82) \\
3,690(110) \\
4,330(310) \\
2,140(430) \\
1,310(110) \\
679(118)\end{array}$ & $\begin{array}{rr}107 & (43) \\
60 & (6) \\
58 & (25) \\
137 & (34) \\
76 & (31) \\
89 & (14) \\
72 & (28) \\
50 & (13) \\
283 & (134) \\
390 & (260) \\
155 & (41) \\
179 & (95) \\
217 & (79) \\
106 & (50) \\
42 & (9) \\
11 & (2) \\
990 & (71) \\
560(126) \\
332 & (26) \\
103 & (15) \\
39 & (3)\end{array}$ & $\begin{array}{l}53(16) \\
99(56) \\
72(16) \\
50(14) \\
25(4) \\
67(27) \\
53(16) \\
44(19) \\
90(22) \\
32(20) \\
39(11) \\
66(21) \\
29(9) \\
21(5) \\
18(4) \\
1 *(1) \\
41(8) \\
32(16) \\
13(2) \\
4 \\
0\end{array}$ & $\begin{array}{r}1,840(450) \\
2,280(190) \\
1,430(270) \\
1,520(210) \\
1,110(220) \\
1,130(260) \\
944(140) \\
1,170(50) \\
1,780(130) \\
790(227) \\
710(197) \\
602(440) \\
72(11) \\
155(34) \\
66(26) \\
105(44) \\
1,260(440) \\
106(13) \\
52(24) \\
72(28) \\
13(1)\end{array}$ & $\begin{array}{rr}240 & (91) \\
82 & (38) \\
104 & (9) \\
162 & (29) \\
49 & (15) \\
69 & (27) \\
105 & (22) \\
147 & (76) \\
277 & (55) \\
226 & (82) \\
111 & (15) \\
66 & (41) \\
27 & (9) \\
43 & (18) \\
4 * & \\
9 & (1) \\
358(217) \\
32 & (16) \\
15 & (8) \\
11 & (5) \\
3 & (1)\end{array}$ \\
\hline Controls & & $1,040(90)$ & 151 (17) & $104(12)$ & $4,450(260)$ & $275 \quad(22)$ \\
\hline
\end{tabular}

Standard errors in parentheses. * Standard errors omitted as, in each case, one of the animals gave a zero value. 
was also due to the neutrophilia. The lymphopenia was greater after $600 \mathrm{r}$ than after $100 \mathrm{r}$, but the neutrophilia after $600 \mathrm{r}$ counteracted the decrease in lymphocytes and consequently the total white cell counts for the two doses were very similar. The variations encountered in the data of the response of the neutrophils to the dose (Table I) were also due to the absence of the neutrophilia at low doses and its increasing magnitude and duration at higher doses.

\section{Discussion}

In dealing with large numbers of radiation casualties, either civil or military, the aim should be to separate them into three groups, namely, (1) those who will need little if any immediate treatment because they have received only a small dose of radiation; (2) those who have received a dose which may kill and may therefore need the whole gamut of transfusion therapy including marrow grafts (leader, British Medical Journal, 1958 ; Mathé, Jammet, Pendic, Schwarzenberg, Duplan, Maupin, Latarjet, Larrieu, Kalic, and Djukie, 1959); and (3) those who, having received a supralethal dose, will die within a few days in spite of treatment. In the present experimental study the three doses used to obtain the data shown in Fig. 2 and Table II (i.e., 100 r, 600 r, and 5,000 r) produce effects in the rat corresponding to the three categories listed above.

It has been suggested that the total white cell count is the best screening procedure to identify casualties whose radiation injury is severe enough to require medical attention (Benjamin, 1958; Sanders et al., 1958). The results of the present investigation, however, show that the total white cell count in the first few hours after exposure gives no indication of the magnitude of the dose of radiation received. It may be seen from Fig. 2 that during the first 18 hours it is impossible to distinguish between groups of animals receiving small doses of radiation (100 r) and those receiving doses likely to kill $(600 \mathrm{r})$. In addition, the total white cell counts of animals which received a supralethal dose $(5,000 \mathrm{r})$ could, during the first 12 hours, have just as easily come from a group of animals which had received little or no radiation. As the mean white cell count of a group does not allow an assessment of the dose received it is even less likely that a count from an individual would give a reliable indication of the degree of radiation damage he had sustained.

It is not only in rats that the total white cell count soon after irradiation is unreliable as an indicator of acute radiation damage. In the rabbit the results reported by Jacobson, Marks, Simmons, Hagen, and Zirkle (1954) show that the mean total white cell count at 24 hours after irradiation lay within $20 \%$ of the control counts for doses ranging from $25 \mathrm{r}$ to $800 \mathrm{r}$. In man the casualties from a reactor accident in Yugoslavia showed a leucocytosis during the first day after irradiation even though the lymphocyte count was falling (Jammet et al., 1959). The disorganization of the medical services following the dropping of the atom bombs on Hiroshima and Nagasaki (Oughterson and Warren, 1956) prevented study of white cell counts over the period now under discussion.

The inadequacy of the total white cell count as an indicator of radiation damage is due to the increase in the neutrophil count which takes place shortly after irradiation. This relatively transient but nevertheless marked neutrophilia is clearly shown in Table II and in the data given by Jacobson et al. (1954) in rabbits and by Jammet et al. (1959) in man. The fact that a neutrophilia may occur after irradiation has been known for over 50 years (Aubertin and Beaujard, 1905; Morris, 1905), and the phenomenon has been repeatedly reported after both therapeutic and accidental irradiation in man (Westman, 192122; Minot and Spurling, 1924; Goodfellow, 1936; Hempelman, Lisco, and Hoffman, 1952; Court Brown and Abbatt, 1955a ; Guskova and Baisogolov, 1956; Bond et al., 1956). It does not, however, seem to have been fully realized that the neutrophilia prevents the total white cell count from being a guide to the degree of radiation damage during the first few hours after exposure.

Ideally the haematological investigation of radiation casualties should include full blood counts, together with platelet counts, reticulocyte counts, and marrow examinations, and the degree of damage should be gauged by the changes occurring in all the cell types. Bond et al. (1956) have suggested that even counts of the very radiosensitive lymphocyte are not reliable except after low doses, and the present results (Table II and Hulse, 1959a) support this contention. Using the lymphocyte count, the lowest of the three doses (100 r) can easily be distinguished from the other two doses, but it is not possible to distinguish groups which received doses which might kill $(600 \mathrm{r})$ from those exposed to supralethal doses $(5,000 \mathrm{r})$. During the first 12 hours after irradiation, however, these latter two groups may be distinguished by the different degrees of neutrophilia, the higher dose giving the greater neutrophilia. Thus if the lymphocyte count is 
taken in conjunction with the degree of neutrophilia a somewhat more reliable assessment might be made. At later time intervals, however, the neutrophilia subsides and consequently the neutrophil count ceases to assist in assessing damage during the period under consideration.

In circumstances when radiation casualties are too numerous to allow a full haematological examination to be made on each individual some other criterion must be sought to judge the severity of radiation damage. The present data (Table II) suggest that at 24 hours after irradiation the eosinophil count may possibly be of value in spite of the large standard errors, particularly as it may be rapidly performed by a "wet" method. It has been shown that the time of onset after exposure and the severity of post-irradiation nausea and vomiting are dependent upon the dose, i.e., the greater the dose the more severe the symptoms and the sooner they occur (Court Brown and Mahler, 1954; Court Brown and Abbatt, 1955b). It would appear, therefore, that clinical assessments of the severity and time of onset of radiation nausea and vomiting could be used as a screening procedure, but vomiting from other causes, particularly psychogenic vomiting, might make the method unsuitable in practice.

I am very grateful to Dr. R. H. Mole for helpful criticism and to Miss B. C. Dempsey for technical assistance.
REFERENCFS Aubertin, C., and Beaujard, E. (1005). C.R. Soc. Biol. (Paris), 58 ,

Benjamin, N. R. (1958). Blood, 13, 677.

Bond, V. P., Cronkite, E. P., Farr, R. S., and Hechter, H. H. (1956) In Some Effects of Ionizing Radiation on Human Beings, p. 43 Ed. E. P. Cronkite, V. P. Bond, and C. L. Dunham. United States Atomic Energy Commission, TID 5358.

Corp, M. J. (1957). Phys. in Med. Biol., 1, 370.

Court Brown, W. M., and Abbatt, J. D. (1955a). Brit. J. Haemat., $1,75$.

(1955b). Brit. J. Radiol., 28, 153.

- and Mahler, R. F. (1954). J. Fac. Radiol. (Lond.), 5, 2 C0.

Goodfellow, D. R. (1936). Acta radiol. (Stockh.), 17, 1.

Guskova, A. K., and Baisogolov, G. D. (1956). In Proc. int. Conference on the Peaceful Uses of Atomic Energy, Geneva, 1955 , Vol. 11, p. 35. United Nations, New York

Hasterlik, R. J., and Marinelli, L. D. (1956). Ibid., p. 25.

Hempelmann, L. H., Lisco, H., and Hoffman, J. G. (1952). Ann. intern. Med., 36, 279.

Hulse, E. V. (1957). Brit. J. Haemat., 3, 348.

(1959a). Ibid., 5, 278.

- (1959b). Ibid., 5, 369.

Jacobson, L. O., Marks, E. K., Simmons, E. L., Hagen, C. W., and Zirkle, R. E. (1954). In Biological Effects of External $\dot{X}$ and Gamma Radiation, Pt 1, p. 265. Ed. R. E. Zirkle. McGraw-Hill, New York.

Jammet, H., Mathé, G., Pendic, B., Duplan, J. F., Maupin, B. Latarjet, R., Kalic, D., Schwarzenberg, L., Djukic, Z., and Latarjet, R., Kalic, D., Schwarzenberg, L., Dju
Vigne, J. (1959). Rev. franc. Et. clin. biol., 4, 210.

Loutit, J. F. (1955). Brit. J. Radiol., 28, 647.

Mathé, G., Jammet, H., Pendic, B., Schwarzenterg, L., Duplan, J. F., Maupin, B., Latarjet, R., Larrieu, M.-J., Kalic, D., and Djukic Z. (1959). Rev. franc. Et. clin. biol., 4, 226.

Minot, G. R., and Spurling, R. G. (1924). Amer. J. med. Sci., 168, 215 .

Mole, R. H. (1954). J. clin. Path., 7, 267.

Morris, R. S. (1905). Amer. Med. (Philad.), 10, 946.

Oughterson, A. W., and Warren, S. (1956). Medical Effects of the Atomic Bomb in Japan. McGraw-Hill, New York.

Sanders, C., Cox, R., and Sharples, J. B. (1958). A Report on a Suggested Method for the Rapid Determination of "The Total Leucocyte Count," AERE MED R 2700. Atomic Energy Research Establishment, Harwell (available from H.M.S.O.).

Westman, A. (1921-22). Acta radiol. (Stockh.), 1, 349. 